\title{
Pensononowoor
}

2016, vol. 75, 45-54

http://dx.doi.org/10.12657/denbio.075.005

\author{
Dávid Misi, Katalin Náfrádi
}

\section{Possibility of identification of negative extreme climatic events using Pinus sylvestris tree-rings in Transdanubia, Hungary}

\author{
Received: 30 March 2015; Accepted: 9 October 2015
}

\begin{abstract}
Negative climatic extremes occur more frequently in the last decades. Since the Carpathian Basin is highly concerned in their impacts it is important to investigate prior events and estimate the response of the environment to them to get useful information for the future. In our work we selected a stand which is seriously affected by unfavorable summer conditions to examine what kind of fingerprint the negative extreme events have left. We investigated narrow rings and intra-annual density fluctuation to describe years with extreme events. Their stabilized frequency was tested against climatic and groundwater data, as well as against aridity index to determine climate-growth relationships using Pearson and Spearman's correlations. Our results show positive significant correspondence between summer precipitation and treering growth together with negative connection with summer temperature. The Spearman's correlation between stabilized frequency of intra-annual density fluctuations, narrow rings and climate data ended with significant relationship in summer. According to the comparison of intra-annual density fluctuation and narrow ring data with drought periods it can be said that narrow rings are better tool for the examination of negative extreme events in summer.
\end{abstract}

Keywords: Scots pine, intra-annual density fluctuation, narrow ring, drought

Addresses: D. Misi, University of Szeged, Faculty of Science and Informatics, Department of Geology and Paleontology, Egyetem utca 2-6, H-6722, Hungary, e-mail: misid@geo.u-szeged.hu

K. Náfrádi, University of Szeged, Faculty of Science and Informatics, Department of Geology and Paleontology, Egyetem utca 2-6, H-6722, Hungary, e-mail: nafradi@geo.u-szeged.hu

\section{Introduction}

The strong connection between tree-rings and climate is widely known and was investigated numerous times in the past decades (e.g. Briffa et al., 1990; Büntgen et al., 2005, 2006; Douglass, 1914, 1920; Fritts, 1965, 1976; Lough \& Fritts, 1985, Wilson et al., 2005; Woodhouse, 1993). Since nowadays climate trends cause severe extremes, tree-ring re- search turned to the analysis of impacts of extreme events to figure out how the environment responded to them in the past and estimate how it will in the future.

Commonly it can be said that high elevation (especially near to the distribution limit) or severe drought sensitivity are favorable to unusual treering formation. In the literature many types of radial growth features have been discussed like narrow 
rings (e.g. Panayotov et al., 2013), frost rings (e.g. Hantemirov et al., 2004), light rings (e.g. Liang \& Eckstein, 2006) or intra-annual density fluctuation (e.g. Bogino, 2009; Rigling et al., 2001). Narrow rings (NR) are considered as indicators of negative conditions for a long time (Douglass, 1920; Fritts, 1976) but nowadays wood anatomical features such as intra-annual density fluctuation (IADF) are also widely used to detect fingerprints of drought conditions.

In Europe tree-ring studies on negative extreme climatic events are principally concentrated to Mediterranean region (e.g. Campelo et al., 2007, 2013; Cufar et al., 2011; de Luis et al., 2011; De Micco et al., 2014; Olivar et al., 2012) but researches have already been made in temperate forests as well (Ježík, 2011; Nabais et al., 2014; Panayotov et al., 2013; van der Werf, 2007). Tree-ring studies in Hungary have been focused on climate-growth relationship (Babos, 1984; Garamszegi \& Kern, 2014; Kern et al., 2013; Szabados, 2006) and climate reconstruction (Kern et al., 2009) so far, thus dendrochronological approach of the investigation of negative extreme climatic events is still missing.

Due to the climatic and orographic conditions of Hungary there is no prominent dry season neither high areas which highly influences the possibility of investigation of tree-ring parameters related to ex- treme events. We selected a site for the work which is seriously concerned in highly arid summers where, the Pinus sylvestris stand is becoming less tolerant to increasing thermal conditions (Gulyás et al., 2014). We decided to study whether the special circumstances of this area could influence strong enough tree-ring growth to make the stand suitable for investigation of drought events. With this object we set as our aim the analyses of the possibility of identification climatic extremes and determine which tree-ring parameter (IADF or NR) can describe more precisely unfavorable conditions.

\section{Materials and methods}

\section{Study site}

The site of the study (Fenyőfo, N47 $21^{\prime}$, E $17^{\circ} 45^{\prime}$ ) is located in the northern part of Transdanubia, on the northwestern slopes of Bakony Mts in Hungary (Fig. 1). The main elevation of the area is 270 $\mathrm{m}$ a.s.1. with relative fall around $20 \mathrm{~m}$. The forest has been growing on secondarily evolved dune sand and weakly humic sandy soil which were formed on calcareous sand bedrock (Borhidi, 2003). Due to the sandy soil cover the groundwater level is low, in case of arid summers it can subside below the roots

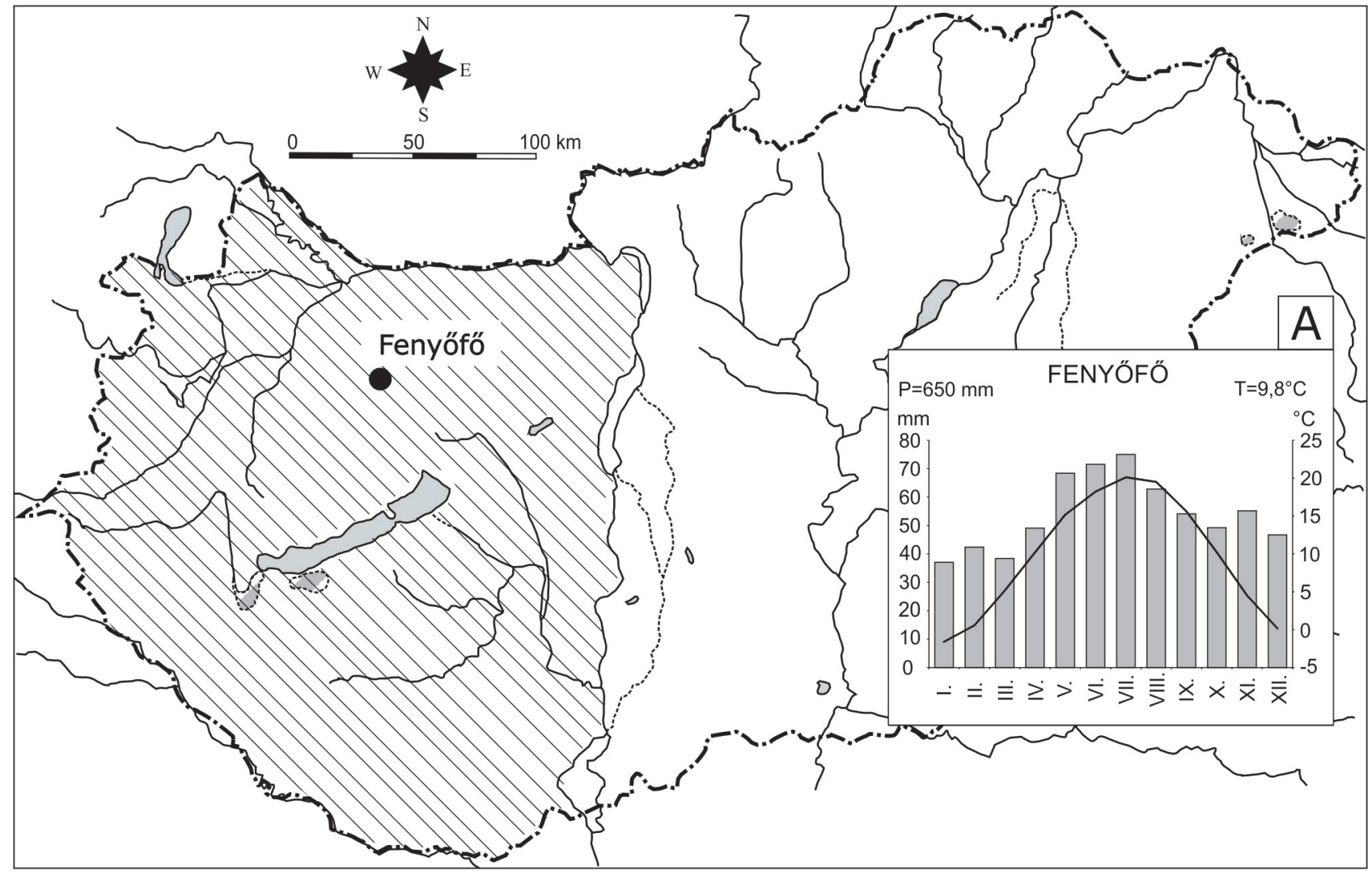

Fig. 1. Location of study site. The cross-hatch represents Transdanubia. A: Long-term (1901-2012) monthly precipitation totals and mean temperature values of the study site 
that causes poor water management and unfavorable conditions to tree growth. This eventuates that Scots pine could keep its dominance against other species of the forest (oak (Quercus cerris, Quercus robur, Quercus petraea), silver birch (Betula pendula) and ash (Fraxinus ornus)). Though the area is out of the natural distribution zone of Pinus sylvestris, the forest is usually called primeval or autochthonous in Hungarian literature (e.g. Majer, 1988; Borhidi, 2003). It is generally accepted that this is a relict phytocoenosis (Festuco vaginatae-Pinetum sylvestris) (Soó, 1931) but its age is a matter of scientific disagreement. The most common point of view that the forest evolved during the Boreal age (7700$5500 \mathrm{BC}$ ) and later principally due to climatic reasons its role become subordinated (Majer, 1988; Kevey, 2008). In contrast, according to Sümegi et al. (2011), the pine forests evolved much earlier, at the end of the last ice age (12000-11000 BC) in the western part of Hungary. Based on palynological results, they could dominate until the rise of human cultures, especially till the development of Neolithic (5000-4000 BC). Because of the agricultural activity and the subsequent deforestation of human communities, only small groups of primeval forests subsisted.

The climate of the region is highly affected by Bakony Mts. The total long-term average annual precipitation is $650 \mathrm{~mm}$, the long-term annual average temperature of the area is $9.8^{\circ} \mathrm{C}$. The precipitation $(75 \mathrm{~mm})$ and temperature $\left(20.1^{\circ} \mathrm{C}\right)$ maximum occurs in July, while the driest and coldest month is January (Fig. 1a). Most of precipitation falls in the vegetation period $(430 \mathrm{~mm})$.

\section{Tree-ring data}

During the current study we used samples of 19 old, dominant and healthy trees (2 samples/tree) which were air-dried, sanded and polished with 8 different sandpapers to enhance tree-ring structure. The measurement of tree-ring widths was done with LINTAB Measurement Station in $0.01 \mathrm{~mm}$ precision, from the pith to the bark (Rinn, 2003). All individual series were added to the final chronology but in case of samples exceeding our study period we deleted rings which were formed before 1913. On-screen crossdating of individual series was done by program TSAPX, series intercorrelation, missing ring identification and detection of possible dating errors were checked by program COFECHA (Holmes, 1983). To remove the non-climatic signal from tree-ring widths cubic smoothing spline with a $50 \%$ frequency response at $67 \%$ length of the individual series was applied (Cook \& Peters, 1981). Autocorrelation was removed from each individual index, then all detrended series were averaged to chronology using biweight robust mean (Cook, 1985) with program ARSTAN (Cook \& Krusic, 2006).

The appearance of intra-annual density fluctuation (IADF) or exceptionally narrow rings (NR) implies to extreme conditions during the vegetation period. In our samples reduced growth affected both earlywood and latewood formation but with different weight. Normally earlywood's width is not only wider than latewood's same value but it shows much smaller fluctuation in size. In case of NR formation latewood has higher decrease in width but the reduced growth is observable in earlywood as well. It is also important to note that if narrow ring formation lasts for more than one year (in our case it happened in the 1960's and in the 2000's as well) level of earlywood development decreases in every year, which highlights the role of environmental conditions in prior years of tree-ring growth. IADFs are usually separated to and investigated in at least two groups depending if they have formed of E-rings (latewood-like cells in earlywood) or L-rings (earlywood-like cells in latewood) (Campelo et al., 2007, 2013; de Luis et al., 2011). In the current study we only took account of L-rings because of very low amount of E-rings in the samples. A year was considered as a year with IADF or NR if they appeared in both samples of a given tree and occurred in at least 3 trees in the same year. The relative frequency of IADFs and NRs per year $\left(\mathrm{F}_{\mathrm{IADF}}\right)$ and $\left(\mathrm{F}_{\mathrm{NR}}\right)$ was calculated as

$$
\mathrm{F}=\mathrm{N} / \mathrm{n}
$$

where $N$ is the number of trees that present IADF or NR in a given year and $n$ is the total number of analyzed trees in that year. To avoid the bias in the frequency caused by the changing sample depth (n) over the study period we calculated stabilized IADF $\left(f_{\text {IADF }}\right)$ and NR $\left(f_{\mathrm{NR}}\right)$ frequency according to the formula of Osborne et al. (1997):

$$
f=\mathrm{Fn}^{0.5}
$$

where $F$ is the relative frequency of IADF or NR and $n$ is the replication in a given year. The relationship between $f$ series, climate and groundwater data was calculated using Spearman's rank order correlation from January to December of the current year of treering formation and for combined periods (see below).

\section{Climate signal}

To analyze the climatic conditions gridded (CRU TS $3.21,0.5^{\circ} \times 0.5^{\circ}$ ) monthly and seasonal precipitation and temperature data have been used for the period of 1901-2012 (Jones \& Harris, 2013). To evaluate the relationship between meteorological 
data and tree-ring width we calculated Pearson correlation coefficient ( $r$ ) from May of the previous year (pMay) to December of the current year (DEC) of tree-ring formation. Combinations of monthly temperature and precipitation data (JJA - June, July, August; MJJ - May, June, July; SPR - March, April, May; VGP - March - October) against radial growth were also calculated to investigate the impact of longer periods on tree-ring formation. For the examination of stability of climate-related signal preserved in the index series Expressed Population Signal (EPS) was computed with 25 -years windows lagged by 5 years using 0.85 as a widely accepted threshold (Wigley et al., 1984). In addition, mean interseries correlation (Rbar) was applied with the same windows and lags than in case of EPS.

Since our purpose was to study negative extreme events we calculated an aridity index to determine drought conditions during the study period. Calculation was carried out using precipitation and temperature anomalies as

$$
\mathrm{AI}=((\mathrm{T}-\mathrm{Tm}) / \mathrm{Td})-((\mathrm{P}-\mathrm{Pm}) / \mathrm{Pd})
$$

where $T$ is the temperature, $T m$ is the mean temperature of the reference period, $T d$ is the deviation of the reference period temperature, $P$ is the precipitation, $P m$ is the mean precipitation of the reference period and $P d$ is the deviation of the reference period precipitation. Computation was made for every months of the current year of tree-ring formation and was for the above mentioned monthly combinations. AI values were tested against meteorological data with Pearson correlation coefficient and against IADF and NR data with Spearman's rank order correlation.

As groundwater level is good indicator of drought conditions we calculated Pearson and Spearman's correlation coefficients between its value and climate data, IADF and NR frequency. Annual groundwater dataset was provided by Central-Transdanubian Water Directorate from the monitoring well of Lovászpatona from 1970 to 2012.

All correlation processes were made by SPSS Statistics 17. (Argyrous, 2005).

\section{Results}

\section{Tree-ring chronology}

In course of the study we focused on the last 100 years. In total 1549 tree-rings were measured to build up the final chronology that spans from 1913 to 2012. Replication starts with 5 trees in 1913 and reaches its maximum in 1982 with 19 trees (Fig. 2).

\section{Climate-growth relationship}

The climate-related signal analysis ended with stable high correspondence during the whole period. EPS values exceed the widely accepted 0.85 level in the entire time-scale, and after the 1930s they transcend the currently recommended higher critical level (approx. 0.90) (Mérian et al., 2013) as well. The interseries correlation test shows strong relationship between the individual series with 0.48 mean (Fig. 2 ). These results suggest that the chronology carries a reliable climate signal and suitable to represent the whole Fenyőfó Scots pine stand.

According to our results precipitation that falls in MJJ period plays the main role in tree-ring growth in our study area. The most important month is July but there is significant connection between tree-ring formation and precipitation in June, May and the previous September as well. While temperature has only secondary influence on radial increment, its effect in August and prior September is negative whilst positive at the beginning of the vegetation period (February, March) (Fig. 3).

In the correlation of AI values and climate conditions, JJA period has the biggest impact with maximum in July (Fig. 3). The strong correspondence between aridity index and tree-ring data suggest that even if thermal conditions has secondary effect on radial increment, they are remarkable factor of tree-


Fig. 2. Statistics of Pinus Sylvestris chronology of Fenyőfo" 


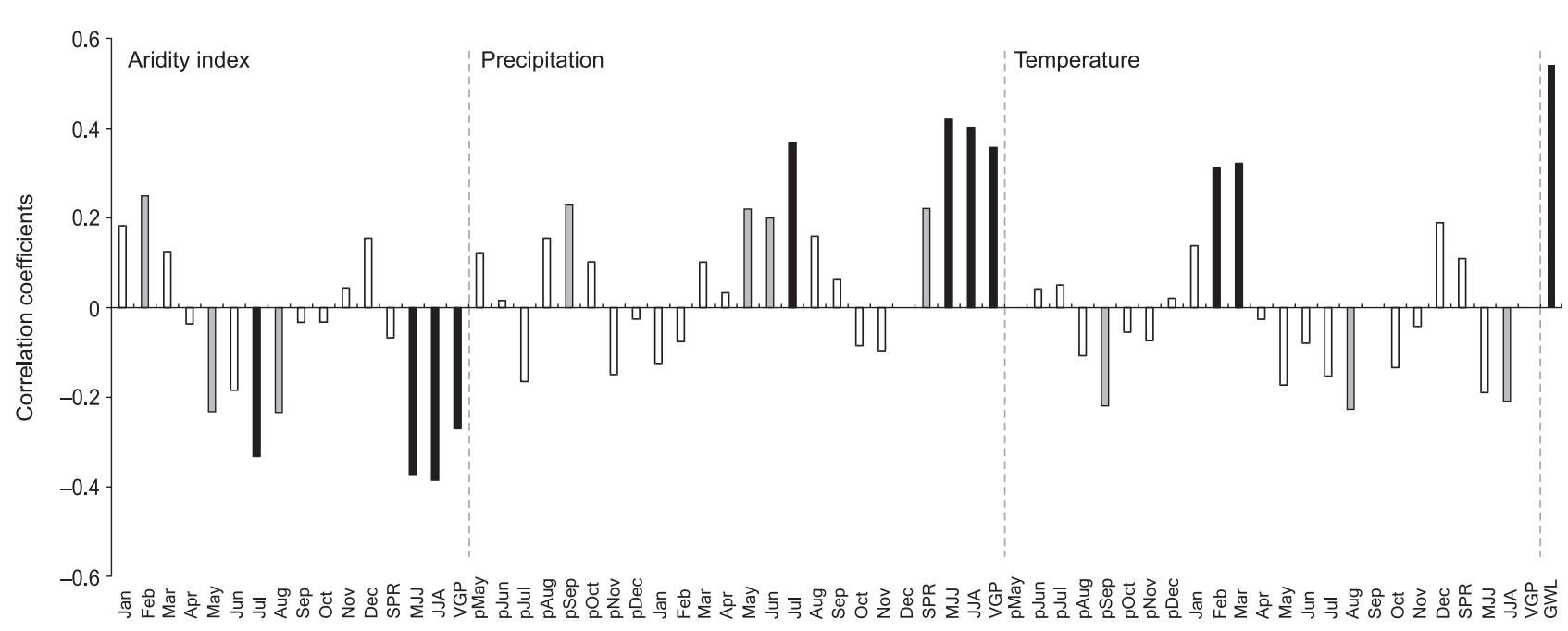

Fig. 3. Pearson correlation values between tree-ring index and climate data (precipitation, temperature, aridity index). MJJ (May-June-July), JJA (June-July-August), SPR (March-April-May) and VGP (March-October) represent the combined periods, GWL shows groundwater data. Filled bars mark the significant correlations at 0.05 (grey bars) and 0.01 (black bars) level

ring growth with the influence on available precipitation. This is confirmed by the fact that tree-ring index shows strong relationship with groundwater data which substantially depends on thermal conditions.

\section{Marks of negative extreme events}

Approximately $17 \%$ of all investigated tree-rings were classified as IADF or NR. The most dominant feature was IADF; we found intra-annual density fluctuation in 178 tree-rings $(11.5 \%)$. Not only the amount of narrow rings was much lower, 84 in total (5.4\%), their distribution has a different characterization as well. In contrast with the uniform distribution of IADF, NRs are concentrated in four groups.

As a direct source of tree-ring information raw chronology shows the relative impact of NRs on the natural dynamics of tree-ring formation. Although at this level non-climatic signal is still in the dataset it is evidently visible that events at the beginning of 1960's and 2000's affected the most the tree-ring growth (Fig. 2). In total we found 47 narrow rings in these periods which are $56 \%$ of the entire amount. Nevertheless, the highest stabilized frequency occurred in 1993 with 11 samples of 19 trees. Spearman's rank correlation analysis shows that temperature in July $(r=0.205)$ and August $(r=0.228)$ has significant effect on NR formation but the strongest correspondence occurs in cases of JJA and VGP $(r=0.263)$ periods (Fig. 4b). This results underline the role of hot summers on narrow ring formation.

Considering the fact that much of IADFs occurred in the latewood constituting earlywood-like cells, it was expectable that summer conditions, especially thermal circumstances will be accountable for their development. Spearman's correlation analysis shows that the warmer than average late-springs and sum- mers are the most favorable conditions for their formation in our study site. The strongest positive relationship between IADF stabilized frequency and climate data occurs in May, June and August as well as in the combined SPR, MJJ, JJA and VGP periods. In contrast, spring and summer precipitation has negative effect on intra-annual density fluctuation (Fig. $4 a)$. This pattern is even more highlighted in the correlation values between IADF and aridity index that shows strong correspondence in the SPR period with maximum values in May.

It is doubtless that normal tree-ring formation requires sufficient amount of water thus we expected strong correlation between groundwater data and stabilized frequency of IADF and NR. Since groundwater data was not provided for the entire study period we carried out the correlation calculation from 1970 to 2012. This resulted in significant and strong relationship only in case of narrow rings. According to this result narrow ring formation principally depends on groundwater level and occurs in years described with extreme low values of it.

\section{Discussion and conclusion}

The above presented pattern of climate-growth relationship, namely the positive dominance of summer precipitation and negative impact of summer temperature was reported in other studies in Hungary on beech (Garamszegi \& Kern, 2014) and on oak (Kern et al., 2013) and was observed many times on pine (Koprowski, 2012; Michelot, 2012; Panayotov et al., 2013; Levanič, 2015; Toromani et al., 2015) as well. However, we found a much unusual pattern also, which has never been observed in Hungary neither on pines nor on other species, but rare in the 


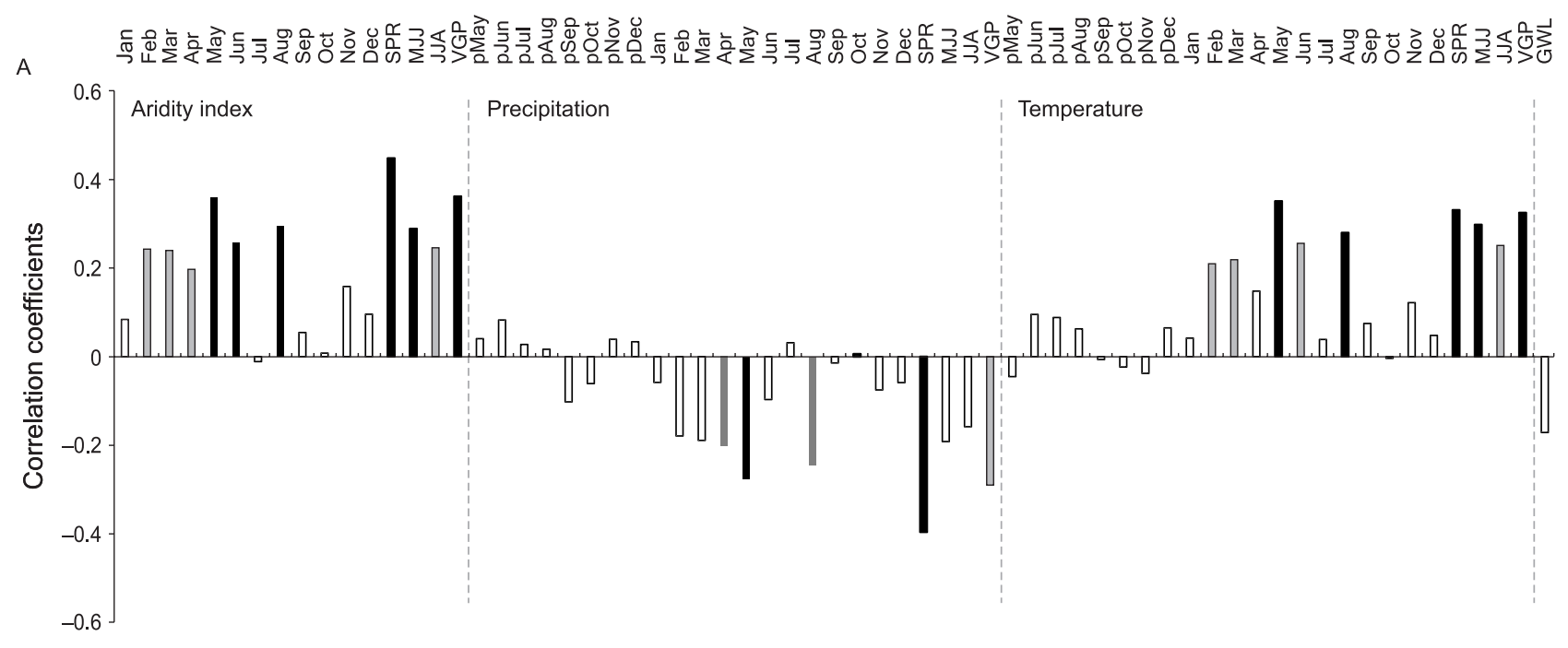

B

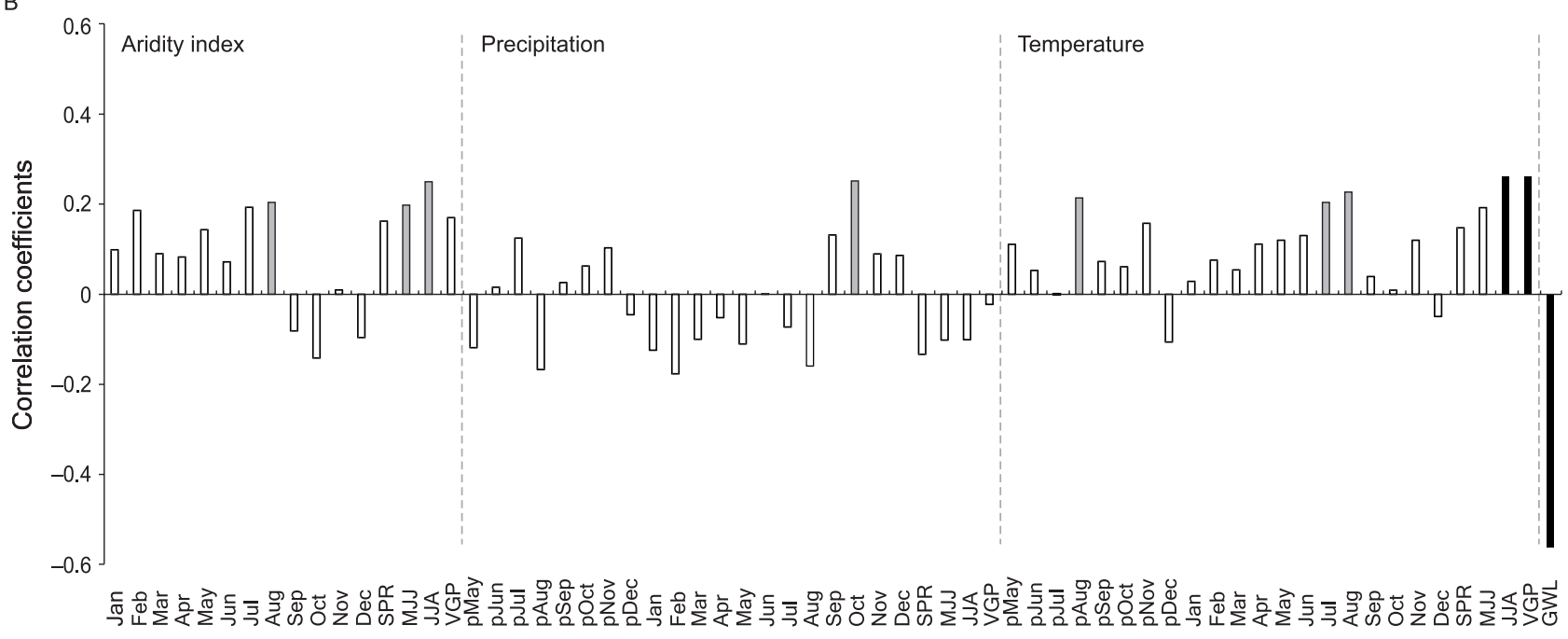

Fig. 4. Spearman's rank correlation values between stabilized frequency of intra-annual density fluctuation (a) and narrow rings (b) and climate data (precipitation, temperature, aridity index). MJJ (May-June-July), JJA (June-July-August), SPR (March-April-May) and VGP (March-October) represent the combined periods, GWL shows groundwater data. Filled bars mark the significant correlations at 0.05 (grey bars) and 0.01 (black bars) level

region as well. This is the strong positive correlation between late winter-early spring (February, March) temperature and tree-ring growth. The phenomenon which is obviously connected to the thermal conditions of the onset of vegetation period was detected in Poland by Koprowski (2012) who noted the longterm effect of increasing early spring temperature on the stability of this signal as well.

Investigating unusual tree-ring characters we found significant connection between climate data and both narrow ring formation and intra-annual density fluctuation. According to the above presented results narrow ring development is controlled by thermal conditions of July and August and is highly affected by groundwater level. The earlier mentioned distribution with 4 well-separated periods of NR formation fits aright to the serious drought periods of the last 50 years (Pálfai, 2011) in Hungary. Never- theless, earlier, even though at least two dominant drought periods occurred (1928-1932, 1945-1947) we could not recognize narrow rings at all (Fig. 5). Its reason may be the trees lower tendency for narrow ring formation in young ages. While narrow rings are usually connected to extreme events during the vegetation period (e.g. Fritts, 1976; Panayotov et al., 2013; Vaganov et al., 2006) we also found narrow rings which were formed because of winter conditions. The reason of high number of NRs in 1963 is a serious snow damage that occurred in November of 1962 and caused extended damage in the pine stand (Kósa, 1963). There was not much time to recover because in winter of 1963 rime accumulation made sever demolition in the forest (Papp, 1966). The damage of crown, together with the coldest winter period in the last 50 years (1962-1965), proved to be strong enough to result in extended growth re- 


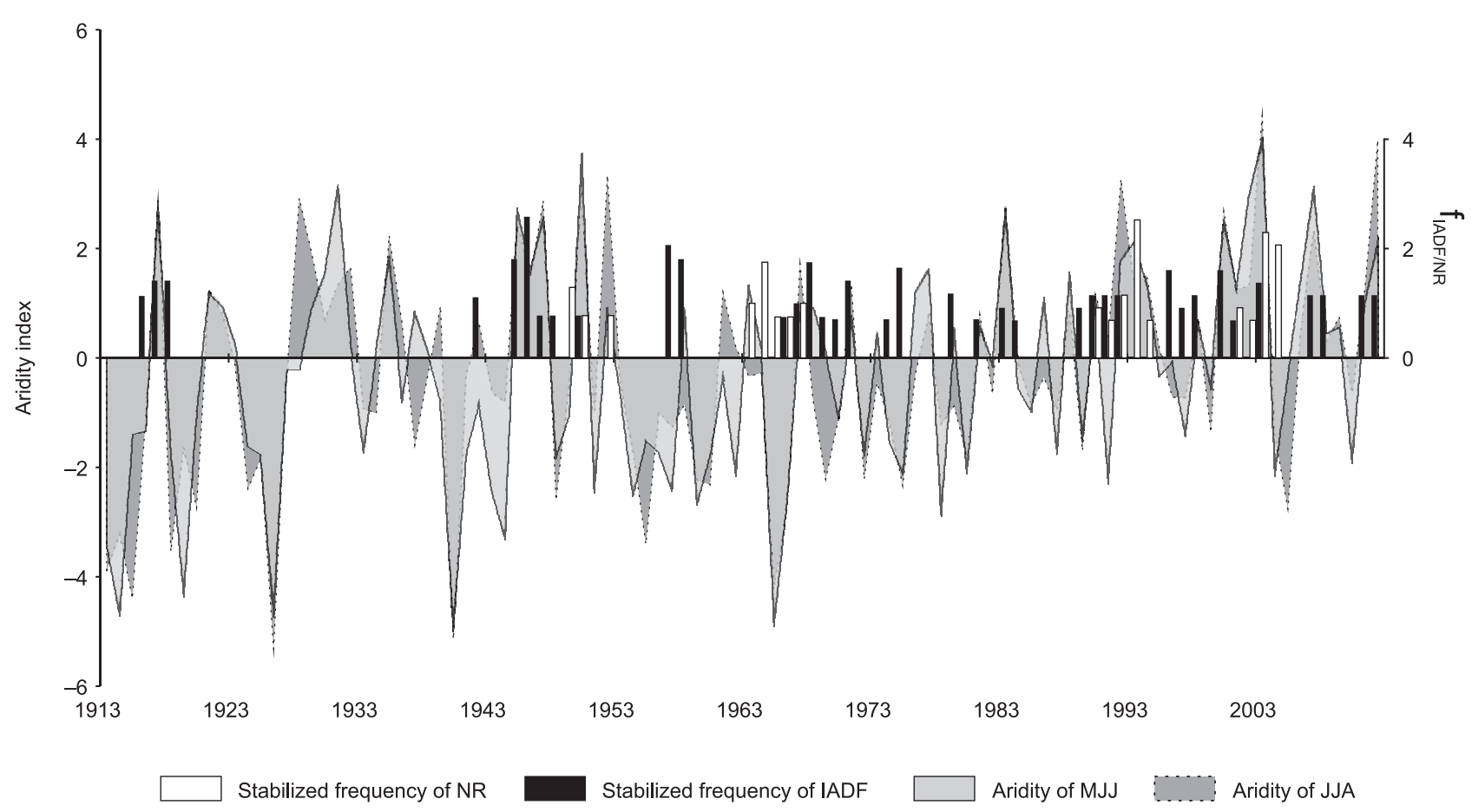

Fig 5. Aridity index calculated for the period of MJJ and JJA and stabilized frequency of narrow ring and intra-annual density fluctuation

duction (Panayotov, 2007; Schweingruber, 1996) and effected the early and latewood formation for at least 3 years. Without taking account of the years concerned in winter damages $(1963,1964$ and most likely 1965) Spearman's correlation values between stabilized narrow ring frequency and climate data are considerably increasing in July and August which shows that normally summer conditions lead to NR formation in our study site. Rybníček et al. (2015) have also found significant narrow ring periods in oak samples in the middle of 1960's and in the beginning of 1990's. According to their results reduced treering growth in 1993 in southern Czech Republic was caused by hot and dry spring and summer in 1992 which can be paralleled to our observations. Moreover, besides the lower than average precipitation and high temperature in summer, they explained narrow ring formation in 1964 with winter conditions from December 1963 to April 1964 which also shows similarities with our results. Another correspondence to our data can be found in Opala's (2015) paper where 1952 was picked as a negative pointer year (among others) and explained its formation with drought. Although some resemblances to our results can be found from the surrounding countries, considering the whole dataset we can say that NR formation depends on local factors principally (drought, winter conditions, groundwater level) in our study site.

Whereas NRs indicated the most extreme events only, intra-annual density fluctuations occurred much frequently in the last 100 years. While in the Mediterranean region IADF is reliable mark of sum- mer drought in temperate forests it cannot be connected to it unequivocally (Panayotov et al., 2013). In our samples most of the observed IADFs were located in the very first part of latewood which allude to that main driver of their formation occurs in the early period of latewood development. The result of Spearman's rank correlation shows that climatic conditions of May have the highest impact on IADF. It means that in contrast with the Mediterranean area, in our temperate study site principally not extreme summer drought but first of all high late-spring and just secondly summer temperature lead to tracheid wall thickness decrease and tracheid lumen area increase which causes intra-annual density fluctuation in latewood (Vaganov et al., 2006). This effect is visible in years such as 1957, 1958, 1975, 1979, 1996, 1997 when while formation of intra-annual density fluctuation was not reasonable by climatic conditions, we observed significant amount of it. Similar to NRs we barely found IADFs in the first part of the chronology that may strengthen our concept about the lower tendency of unusual tree-ring formation in young ages.

As a sum of our results we can say that the growth of Fenyőfó stand is strongly affected by climatic conditions and is sensitive to extreme events. Investigation of unusual tree-ring features generally prove to be a useful tool to analyze exceptionally arid periods but as our results show they cannot be connected only to them in our study site. While narrow ring frequency was lower they indicated serious drought events better but as it was presented winter process- 
es affected their development as well. While relative high number of IADFs described several arid periods, their formation cannot be connected only to drought in this temperate forest. With an outlook to the further work we can say that narrow ring analyses could be the better tool to the reconstruction of drought events. Its common use with IADF data may provide more information about late spring and summer conditions but detailed data analysis is essential.

\section{Acknowledgments}

The authors would like to express their gratitude to Ms. Katarina Cufar and her team for the guidance during the work. We thank also to reviewers for their valuable advices and comments. This work has been carried out under the framework of the COST FP1106 network STReESS.

\section{References}

Argyrous G (2005) Statistics for Research with a guide to SPSS. Sage Publications.

Babos K (1984) A csertölgy és néhány más fafaj évgyưrűszélesség és az éves csapadék összefüggés-vizsgálata. Botanikai Közlemények 71: 123132.

Bogino S \& Bravo F (2009) Climate and intraannual density fluctuations in Pinus pinaster subsp. mesogeensis in Spanish woodlands. Canadian Journal of Forest Research 39: 1557-1565.

Borhidi A (2003) Magyarország növénytársulásai. Akadémiai Kiadó, Budapest.

Briffa KR, Bartholin TS, Eckstein D, Jones PD, Karlén W, Schweingruber FH \& Zetterberg P (1990) A 1,400-year tree-ring record of summer temperatures in Fennoscandia. Nature 346: 434-439.

Büntgen U, Esper J, Frank DC, Nicolussi K \& Schmidhalter M (2006) A 1052-year tree-ring proxy for Alpine summer temperatures. Climate Dynamics 25: 141-153.

Büntgen U, Frank DC, Nievergelt D \& Esper J (2006) Summer temperature variations in the European Alps, A.D. 755-2004. Journal of Climate 19: 5606-5623.

Campelo F, Nabais C, Freitas H \& Gutiérrez E (2007) Climatic significance of tree-ring width and intra-annual density fluctuations in Pinus pinea from a dry Mediterranean area in Portugal. Annals of Forest Science 64: 229-238.

Campelo F, Vieira J \& Nabais C (2013) Tree-ring growth and intra-annual density fluctuations of Pinus pinaster responses to climate: does size matter? Trees 27: 763-772.

Cook ER \& Krusic PJ (2006) ARSTAN4.1b_XP. http://www.ldeo.columbia.edu.
Cook ER \& Peters K (1981) The smoothing spline: a new approach to standardizing forest interior tree-ring width series for dendroclimatic studies. Tree-Ring Bulletin 41: 45-53.

Cook ER (1985) A Time Series Analysis Approach to Tree-ring Standardization. Ph.D. dissertation, The University of Arizona, Tucson.

Cufar K, Cherubini M, Gricar J, Prislan P, Spina S \& Romagnoli M (2011) Xylem and phloem formation in chestnut (Castanea sativa Mill.) during the 2008 growing season. Dendrochronologia 29: 127-134.

de Luis M, Novak K, Raventós J, Gričar J, Prislan P \& Čufar K (2011) Climate factors promoting intra-annual density fluctuations in Aleppo pine (Pinus halepensis) from semiarid sites. Dendrochronologia 29: 163-169.

De Micco V, Battipaglia G, Cherubini P \& Aronne G (2014) Comparing methods to analyse anatomical features of tree rings with and without intra-annual density fluctuations (IADFs). Dendrochronologia 32: 1-6.

Douglass AE (1914) A method of estimating rainfall by the growth of trees. Bulletin of the American Geographical Society 46: 321-335.

Douglass AE (1920) Evidence of climatic effects in the annual rings of trees. Ecology 1: 24-32.

Fritts HC (1965) Tree-ring evidence for climatic changes in western North America. Monthly Weather Review 93: 421-443.

Fritts HC (1976) Tree rings and climate. The Blackburn Press, New Jersey.

Garamszegi B \& Kern Z (2014) Climate influence on radial growth of Fagus sylvatica growing near the edge of its distribution in Bükk Mts., Hungary. Dendrobiology 72: 89-97.

Gulyás K, Bidló A \& Horváth A (2014) Causes of the Forest Die-off in a Pinus Forest (Pinus sylvestris) in Fenyőfö: Local and regional challenges of climate change adaptation and green technologies. Proceedings. (ed. by A Polgár, T Bazsó, G Nagy \& B Gálos) Sopron, Hungary, pp. 60-67.

Hantemirov RM, Gorlanova LA \& Shiyatov SG (2004) Extreme temperature events in summer in northwest Siberia since AD 742 inferred from tree rings. Palaeogeography, Palaeoclimatology, Palaeoecology 209: 155-164.

Holmes RL (1983) Computer-assisted quality control in tree-ring dating and measurement. TreeRing Bulletin 43: 69-78.

Ježík M, Blaženec $M$, Střelcová $K$ \& Ditmarová L (2011) The impact of the 2003-2008 weather variability on intra-annual stem diameter changes of beech trees at a submontane site in central Slovakia. Dendrochronologia 29: 227-235.

Jones PD \& Harris I (2013) CRU TS3.21: Climatic Research Unit (CRU) Time-Series (TS) Version 
3.21 of High Resolution Gridded Data of Monthby-month Variation in Climate (Jan. 1901 - Dec. 2012), University of East Anglia Climatic Research Unit (CRU)

Kern Z, Grynaeus A \& Morgós A (2009) Reconstructed precipitation for Southern Bakony Mountains (Transdanubia, Hungary) back to AD 1746 based on ring widths of oak trees. Időjárás 113: 299314.

Kern Z, Patkó M, Kázmér M, Fekete J, Kele S \& Pályi Z (2013) Multiple tree-ring proxies (earlywood width, latewood width and $\delta 13 \mathrm{C}$ ) from pedunculate oak (Quercus robur L.), Hungary. Quaternary International 239: 257-267.

Kevey B (2008) Magyarország erdőtársulásai. Tilia 14: 3-489.

Koprowski M (2012) Long-term increase of March temperature has no negative impact on tree rings of European larch (Larix decidua) in lowland Poland. Trees 26: 1895-1903.

Kósa E (1963) Az erdeifenyő jelentősége és egészségi állapota a Bakonyszentlászló környéki erdőben. Diplomadolgozat. Nyugat-magyarországi Egyetem, Sopron.

Levanič T, Poljanšek S \& Toromani E (2015) Early summer temperatures reconstructed from black pine (Pinus nigra Arnold) tree-ring widths from Albania. The Holocene 25: 469-481.

Liang E \& Eckstein D (2006) Light rings in Chinese pine (Pinus tabulaeformis) in semiarid areas of north China and their palaeo-climatological potential. New Phytologist 171: 783-791.

Lough JM \& Fritts HC (1985) The Southern Oscillation and tree rings: 1600-1961. Journal of Climate and Applied Meteorology 24: 952-966.

Majer A (1988) Fenyves a Bakonyalján. Akadémiai Kiadó, Budapest.

Mérian P, Pierrat J-C \& Lebourgeois F (2013) Effect of sampling effort on the regional chronology statistics and climate-growth relationships estimation. Dendrochronologia 31: 58-67.

Michelot A, Bréda N, Damesin C \& Dufrene E (2012) Differing growth responses to climatic variations and soil water deficits of Fagus sylvatica, Quercus petraea and Pinus sylvestris in a temperate forest. Forest Ecology and Management 265: 161-171.

Nabais C, Campelo F, Vieira J \& Cherubini P (2014) Climatic signals of tree-ring width and intra-annual density fluctuations in Pinus pinaster and Pinus pinea along a latitudinal gradient in Portugal. Forestry 87: 598-605.

Olivar J, Bogino S, Spiecker H \& Bravo F (2012) Climate impact on growth dynamic and intra-annual density fluctuations in Aleppo pine (Pinus halepensis) trees of different crown classes. Dendrochronologia 30: 35-47.
Opala M (2015) The 443-year tree-ring chronology for the Scots pine from Upper Silesia (Poland) as a dating tool and climate proxy. Geochronometria 42: 41-52.

Osborn T, Briffa K \& Jones PD (1997) Adjusting variance for sample-size in tree-ring chronologies and other regional-mean timeseries. Dendrochronologia 15: $1-10$

Pálfai I (2011) Aszályos évek az alföldön 1931-2010 között: Környezeti változások és az Alföldön. (ed. By J Rakonczai) Nagyalföld Alapítvány Kötetei 7. Békéscsaba, pp. 87-97.

Panayotov M (2007) Influence of ecological factors on the growth of the tree species from Pinaceae family at the Bulgarian treeline. PhD thesis, University of Forestry, Sofia.

Panayotov M, Zafirov N \& Cherubini P (2013) Fingerprints of extreme climate events in Pinus sylvestris tree rings from Bulgaria. Trees 27: 211-227

Papp L (1966) Időjárási kártételek a fenyvesekben: A fenyők termesztése. (ed. By B Keresztesi). Akadémiai Kiadó, pp. 428-441.

Rigling A, Waldner PO, Forster T, Bräker OU \& Pouttu A (2001) Ecological interpretation of tree-ring width and intraannual density fluctuations in $\mathrm{Pi}$ nus sylvestris on dry sites in the central Alps and Siberia. Canadian Journal of Forest Research 31: 18-31.

Rinn F (2003) TSAP-Win Time Series Analysis and Presentation for Dendrochronology and Related Applications. User Reference, Heidelberg.

Rybníček M, Čermák P, Žid T, Koláŕ, T, Trnka M \& Büntgen U (2015) Exploring growth variability and crown vitality of Sessile oak (Quercus petraea) in the Czech Republic. Geochronometria 42: 1727.

Schweingruber FH (1996) Tree rings and environment. Dendroecology. Paul Haupt Verlag, Berne.

Soó R (1931) Adatok a Balatonvidék vegetációjának ismeretéhez III. Magyar Biolológia Kutató Intézet Munkái 4: 293-319.

Sümegi P, Náfrádi K \& Törőcsik T (2011) Holocene vegetation history in the Alpine Foreland at Szombathely-Zanat, western Hungary: Workshop on landscape history (ed. by P Balázs \& E Konkoly-Gyuró) University of West Hungary, Sopron, pp. 161-176.

Szabados I (2006) The effect of the precipitation on tree ring width. Carpathian Journal of Earth and Environmental Sciences 1: 39-44.

Toromani E, Pasho E, Alla QA, Mine V \& Çollaku N (2015) Radial growth responses of Pinus halepensis Mill. and Pinus pinea L. forests to climate variability in western Albania. Geochronometria 42: 91-99.

Vaganov EA, Hughes MK \& Shashkin AV (2006) Growth dynamics of conifer tree rings. Images of 
the past and future environments. Springer Science \& Business Media.

van der Werf GW, Sass-Klaassen UGW \& Mohren GMJ (2007) The impact of the 2003 summer drought on the intra-annual growth pattern of beech (Fagus sylvatica L.) and oak (Quercus robur L.) on a dry site in the Netherlands. Dendrochronologia 25: 103-112.

Wigley TML, Briffa KR \& Jones PD (1984) On the average value of correlated time series, with applications in dendroclimatology and hydrometeorol- ogy. Journal of Climate and Applied Meteorology 23: 201-213.

Wilson RJS, Luckman BH \& Esper J (2005) A 500 year dendroclimatic reconstruction of springsummer precipitation from the lower Bavarian forest region, Germany. International Journal of Climatology 25: 611-630.

Woodhouse CA (1993) Tree-growth response to ENSO events in the central Colorado Front Range. Physical Geography 14: 417-435. 